\title{
THE EBB AND FLOW OF RELIGIOUS EDUCATION IN TURKEY SINCE FEBRUARY 28, 1997
}

\author{
Mehmet Bahçekapilı \\ İzmir Kâtip Çelebi University, İzmir-Turkey
}

\begin{abstract}
This study aims to analyze and assess the ebb and flow of religious education in Turkey since February 28, 1997, after the military intervention also known as a postmodern coup d'état. Although the study focuses on the period after February 28, 1997, it also addresses the historical and political background relevant to this period. Accordingly, the phases of religious education since the early years of the Turkish Republic are treated briefly. In addition to structural and institutional changes regarding religious education, the qualitative and quantitative changes in the field after February 28 are also analyzed. The study reveals a close relationship between the changes in religious education policies and the changes in political life in Turkey. Therefore, the process of February 28 has transformed social and economic life, military structures and education, whereas the legal and structural changes in education have influenced religious education above all. This effect is clearly observed on both religious education institutions and students in these schools. The new era of political changes that began in 2002 introduced a counter-acceleration in religious education, as in the country's general politics. Consequently, fields restricted during the process of the February 28 reforms again underwent a period of expansion. The study concludes that the governmental role in religious education should be minimized, and civil religious education should be supported to become stronger so that the field of religious education can avoid such influence from political changes.
\end{abstract}

Key Words: February 28 process, religious education, Imam-Hatip schools, Qur'ānic courses, civil religious education 


\section{Introduction}

The changes to and tendencies of religious education policies in Turkey's republic period occur in line with political circumstances. Political structures and actors have always influenced religious education policies. However, there is a structure that should not be overlooked because it also prescribes the politics in some ways. Since the foundation of the Turkish Republic, Turkey has included four different social classes: governmental elites (political and bureaucratic structure), social elites (the capital-managing power), the military structure, and the public. The first three can be considered the elites of the new Republic, whereas the last includes "the others."

Instances of political change in Turkey occur due to an alliance or conflict between these four classes. These moments of change have had various effects on religious education. Consistent with such changes, the republic era witnessed some periods when individuals' freedom of religious education was subject to restrictive practices and times when this freedom was expanded.

One of the most noteworthy moments regarding the transformation of religious education in Turkey is the process that began on February 28, 1997. Following the "postmodern coup," some strict and harsh decisions were made about religious education, followed by similar actions.

As one of the important transformative points in Turkish religious education and the focus of our study, the process of February 28 reforms is worth analyzing because the era includes a series of activities consistent with the intention of government to change the society in a specified form and direction. In the words of Subaş1 $(2005 ; 2009)$, the postmodern coup period is the most recent of several reformation processes by the state to "make a man of," "educate," and "tame" the masses that define themselves as conservative and religious. In the wake of social transformation activities that date back to the Republic's early years, the field of religious education faced numerous formal and institutional problems and issues with those who provide and receive services. Due to the multidimensional effects of February 28 on religious education, the changes to and tendencies of education policies require further explanation.

This study seeks to identify structural and institutional changes and tendencies in religious education in the wake of the February 28 reforms. In this respect, the study includes quantitative (changes in 
number of students, teachers, and institutions) and qualitative (changes in educational programs, standards, available opportunities, and tendencies) changes in religious education services from 1997 to 2014. Because after February 28, the progress of religious education occurred in two different periods (1997-2002 and 2002-2014), the changes and tendencies are analyzed in consideration of these subsections.

\section{Background and Phases of Ebb and Flow in Religious Education}

The process of modernization/westernization has notable effects on education in Turkey, particularly on religious education. The westernization, which began in the late Ottoman era and accelerated in the Republic period, has many effects on various domains, including education, law, art, and politics. The modernization process, which was more "occidentalism" than "westernization," is considered to be an important phase of transformation in recent Turkish history (Tuna, 2013: 273).

The main and initial event of Ottoman modernization was Tanzịmāt (Reorganization). The modernization and secularization movements at that time marked an important process of transformation for modern Turkey in social, political, cultural, and economic terms. The reform era that began with Tanzịmāt dominated the relationship between the state and religion in both the Ottoman Empire and the new Republic. This tendency proceeded consistent with westernization. Conversely, although Ottoman reforms to westernize and secularize society were influential on the social, political, and educational aspects of the state, the references to religion, and Islam in particular, are far from over. Nonetheless, a relative relaxation occurred in the relationship between religion and the state (Commins, 1993: 39; Okumuss, 2006: 260).

The effect of Tanżimāt on the relationship between religion and the state places the Reorganization in a remarkable position in Turkish political and educational history. As Başil (1998) indicates, prior to Tanẓimāt, the government system was connected to religion since its foundation or even since the acquisition of the caliphate by the Ottoman Empire. After Tanzīmāt the government system evolved and developed into a semi-religious, secular structure and this process continued until 1924, the date when the caliphate was abolished. In this respect, Tanẓīmāt can be considered an important transformation 
and a first step. On the other hand, since 1924 religion has become a subject of control and supervision by the Turkish government, moreover its effects still resonate on today's political life.

After the Independence War in the early 1920s, no radical reforms to religious education policies occurred, mainly because most deputies in the First Assembly were either religious functionaries or graduates of madrasa (Demirel, 2010). Between 1924 and 1946 in the Republic period, religious education underwent its first radical transformation. The period was vital for construction of new Turkey because the country entered a process of modernization. The dominant Kemalist structure at the time understood modernization differently than it was in the Ottoman Empire. The latter aimed to blend the technique of Western civilization with the moral values of Muslim civilization, whereas the New Republic elite argued that they could realize modernization not through Islam but via "national identity/nationalist ideology." The Turkish nation-state departed from the Islam-based Ottoman worldview and grounded its existence on rejection of the Ottoman heritage. Therefore, the national principles offered the power to transform Turkey and ensure westernization (Cizre, 2005: 123-124). However, nationalism could not be sufficient to assure Turkish modernization and westernization. Another important power was needed to support nationalism: "secularism." According to Kemalist intellectuals, the greatest obstacle in face of modernization reforms was traditional religious conservatism, which had to be fought. Therefore, nationalism and secularism were put into practice to complement one another (Özdalga, 2007: 54). In those days, religious education policy was formed by government interventions on religion and religious education pursuant to requirements and rules of modernization and westernization (İnan, 2007: 12) rather than being based on needs and tendencies of religious life and its actors.

From 1924 to 1946, secularist policies for dismissal of religion from government agencies and its depreciation before society were based on the objective of modernization and building a democratic country. The pre-republican association of religion and government, or religion-based government approach gave way to a political stand which embraces government-based religion in new Republic period (Başgil, 1998: 201). Consequently, the Republic period witnessed the intervention and restriction of the state on religion instead of the opposite.

Another period of important changes to religious education policies was between 1946 and 1980. This period can be called "the mul- 
ti-party system and return of religious education." Teaching of the Qur'ān, once banned, was partially permitted in this era, Imam-Hatip Schools were re-established, and religious higher education began through the establishment of the Faculty of Theology in Ankara and other subsequent High Institutes of Islam throughout Turkey. The curricula of primary and secondary education also incorporated courses on religion in this period.

The civil religious education since the early years of the Republic survived after the 1960s via formations of communities and orders. The designers of the military coup on September 12, 1980 tried to restrict and terminate the uncontrollable civil religious education by means of a "state religion" project. The most apparent indicator of the project is that the course "Religious Culture and Moral Knowledge" became compulsory in primary and secondary education pursuant to Article 24 of the Constitution in 1982.

Another stage of transformation for Turkish religious education was the period between 1980 and 1997. Religious and moral education gained legitimacy before the government because it was assured by the Constitution. In the 1980s, government policy about religion and Islam underwent a radical change in form and content (Cizre, 2005: 107). Having kept the religion under its thumb until 1950, the Turkish state gradually liberalized it for the sake of political unity in the country and to avoid undesirable foreign ideologies. This process of liberalization rendered the religious sphere more advanced and powerful in collaboration with political and economic structures. After the coup of 1980, the military-led government needed to ground its legitimacy on a new base in its relationship with the society. Consequently, the government had to flee from the insularity of the laicmodernist project and recognize Islam, which is the most important indicator of local identity (Cizre, 2005: 109).

\section{February 28 Process and Religious Education}

In the 1990s, in addition to the Motherland Party (ANAP) and Right Path Party (DYP) with a conservative base, there were the Nationalist Task Party (MÇP) under Alparslan Türkeş and the Reformative Democracy Party (IDP) of Aykut Edibali. The most surprising party in this period was the Welfare Party (RP) of Necmettin Erbakan because it represented political Islam beyond conservatism. In 1991, RP participated in general elections together with MÇP and IDP and was elected into parliament with $16,8 \%$ of votes. The change established a 
serious rival for ANAP and DYP who had the voters' support for 11 years (Çakır, 1994: 30).

As of 1991, both the vote rate and political role of RP increased. Primarily considered a mass party, RP diffuses towards a broader base. The local elections in 1993 demonstrated that RP became more popular because the party won metropolitan municipalities of Istanbul and Ankara in addition to the Anatolian, East Anatolian and Southeast Anatolian regions, where lower and middle classes were more common. The rapid rise of the Welfare Party caught the attention of the army, capital, and other bureaucratic powers.

The rise of conservative and political Islamist establishments began with Turgut Özal, and they continued to advance in economic terms as well. As a result, the government and social elite who administered the state collaborated with the army to build a common opposition against political Islam. A notable process of defiance was started by public agencies and institutions and elite and military influence, including "social pressure groups" or "unarmed forces" such as jurisdiction, politics, media, syndicates, and the business world, against the coalition government of RP and DYP established on June 28, 1996. The process peaked on February 28, 1997.

In the wake of the National Security Council (MGK) meeting on February 28, 1997, a series of decisions were made under the title "Measures to be taken to prevent reactionary activities against the regime," in addition to MGK Decision no. 406. At the MGK, the army requested the government to actualize these prescribed decisions. The general intent of these decisions under eighteen articles was to restrict the influence of religion in every domain and to constrict, control, and oversee the religious living spaces. The decrees meant elimination of religious values of the society and the nullification of social will and requests through power (Can, 2010: 13).

A review of MGK decisions reveals three different types of restrictive measures on religion: 1 . Measures to restrict religious activities in social and economic life, 2. Measures to restrict religious activities in military space, and 3. Restrictive measures in education. The first two types are not treated here because they do not relate directly to the transformation of formal and common religious education. The third type is analyzed in detail due to its direct connection with our study. 


\section{Restrictive Measures Concerning Religious Education}

The main reform requests via MGK decisions were about the educational system. Consistent with the intention of fulfilling these requests, the government was given specific advice regarding the actualization of certain legal and structural reforms about education at the MGK meeting. The MGK recommended that the government "realize any administrative or legal regulations to require eight years of compulsory education, transfer the control and responsibility of Qur'ānic courses to the Ministry of National Education (MEB), prevent participation in Qur'ānic courses until the completion of eight years of compulsory education, ensure that the institutions to train religious officials serve the Law on the Unification of Education and train personnel consistent with requirements" (MGKK, 1997). These provisions in MGK decisions signaled radical reforms in three domains by means of transition to continuous education: Qurānnic courses, Imam-Hatip High Schools and faculties of theology.

During the process of the February 28 reforms, the most concrete example of intervention in education is continuous education. The objective was to ensure passage to continuous education as soon as possible. The continuous compulsory education, which came into effect via law no. 4306 on August 18, 1997 following the military intervention on February 28, 1997, is a new form of Turkish modernization under the guidance of the army, state, and social elites.

The underlying reason for continuous education, which was a necessary step for modernization, was the will of the state to keep the public under domination and control (Bahçekapıl1, 2012: 65).

\section{Fields of Intervention on Religious Education after February 28, 1997}

The educational bans and oppression during the process of the February 28 reforms resemble and share a close connection with past practices. The legal and structural reforms in the early years of the Republic were implemented again after February 28 to eliminate the visibility of religious education at the governmental and social levels.

Upon the actualization of the eight years compulsory education law in 1997, the change in the system brought many radical alterations to formal and informal education. Accordingly, in formal education, the primary and secondary schools were unified as "elementary schools" to provide eight years of continuous education, and the sec- 
ondary school section of all vocational high schools, particularly Imam-Hatip, was closed. Conversely, the Qur'ānic courses, arguably the most important element of informal education, were subject to notable restriction. Upon the implementation of the law on continuous education, Imam-Hatip secondary schools were closed, and Imam-Hatip schools became institutions to serve only at the high school level. The law on continuous education was not the sole legal regulation on Imam Hatip. Moreover, a new practice imposed a different coefficient that practically hindered Imam-Hatip graduates from entering any university other than the faculty of theology. The regulation aimed to reduce the desirability of Imam-Hatip schools and cause their eventual "automatic" extinction as in the 1920s because they were already unable to attract sufficient numbers of primary and secondary students and were far from being preferred for university entrance as well.

\section{Changes in Religious Education Institutions from 1997 to 2002}

\section{Legal and Structural Changes Regarding Qur'ānic Courses}

The provision in the MGK decisions that "necessary administrative and legal regulations should come into effect so that Qur'anic courses in which only children who have completed 8 years of basic education can enroll operate under the responsibility and control of the Ministry of National Education" represented a major change in the following process. This MGK decision came into effect in 1999. Pursuant to additional article 3 via Code no. 4415 accepted on July 22, 1999 to Code no. 633 of June 22, 1965 on the establishment and tasks of the Presidency of Religious Affairs, the enrollment in Qur'ānic courses stipulated completion of eight years of compulsory education. ${ }^{1}$ In addition, children must have completed the fifth grade in primary-secondary schools to attend short-term Qur’ānic courses in the summer. These legal regulations are unfortunately questionable based on the Constitution of the Republic of Turkey as well as international conventions such as the European Convention on Human Rights, the Universal Declaration of Human Rights, and the Convention on the Rights of the Child.

Another legal regulation on age limit in Qur'ānic courses is the "Directive by the Presidency of Religious Affairs on Qur'ānic courses, Dormitories and Student Pensions" no. 23982 on May 3, 2000. Both this directive and the eventual instruction pursuant to the directive imposed age limits for Qur’ān learning. 


\section{Quantitative Changes in Qur'ānic Courses}

From 1999 to 2002, there were three types of Qur'ānic courses: (1) long-term courses, (2) courses to train häfiz (people who have memorized the Qur'ān), and (3) summer courses. The number of students and instructors in these courses underwent notable changes between the years mentioned.

Upon the psychological oppression of conservative and religious masses after February 28 and the legal regulations in the same period, the number of students, instructors, and courses underwent a sharp drop in the 1997-1998 academic year. The total number of students in Qur'ānic courses was 173.147 in 1995-1996, but the number fell to 164.308 in 1996-1997 and to 108.829 in 1997-1998. This drop continued for approximately four years, and the number of students had decreased to 95.437 by 2000-2001.

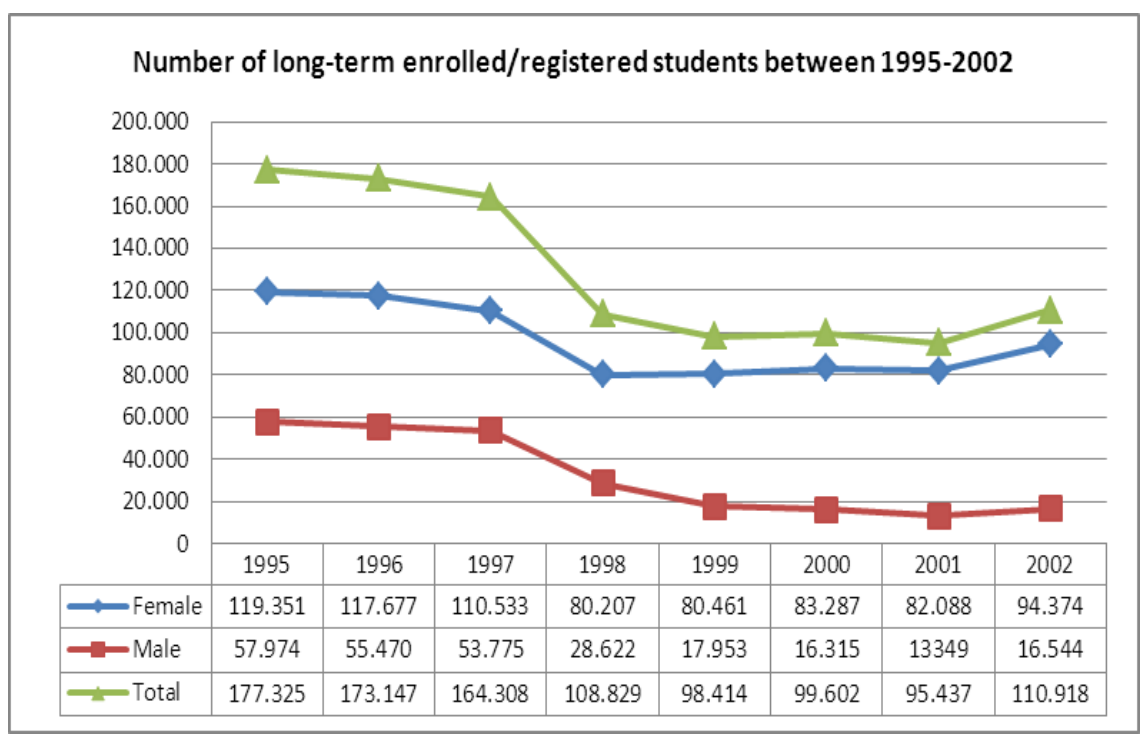

Source: The data were obtained from the Presidency of Religious Affairs of Turkey and Turkish Statistical Institute (TÜİK), 2010: 302-305. ${ }^{2}$

2 There are slight differences between the Turkish Statistical Institute's (TÜİK, 2010: 302-305) data and the figures of the Presidency of Religious Affairs. Although our study is based on TÜIK data, because the student enrollment numbers from 2005 to 2010 are restricted beginning with the spring term, we used the data from the Presidency of Religious Affairs for this period. 
As the students decreased, the number of instructors also dwindled. The number of instructors in Qur'ānic courses was 8.143 in 1995-1996 and 7.783 in 1996-1997, and the figures fell to 5.597 in 1998-1999. The number of instructors continued to decline to $4.541 \mathrm{in}$ the 2001-2002 academic year, when a rise occurred. A radical rupture occurred in the 1996-1997 academic year regarding the gender of students in Qur'ānic courses. The number of boys, approximately 55.000 from 1991 to 1996 , dropped to 28.207 in 1997-1998, 17.953 in 1998-1999, and 13.339 in 2000-2001. This decline in male students is largely due to socio-economic, socio-cultural, and political oppression in the period (Bahçekapil1, 2012: 84).

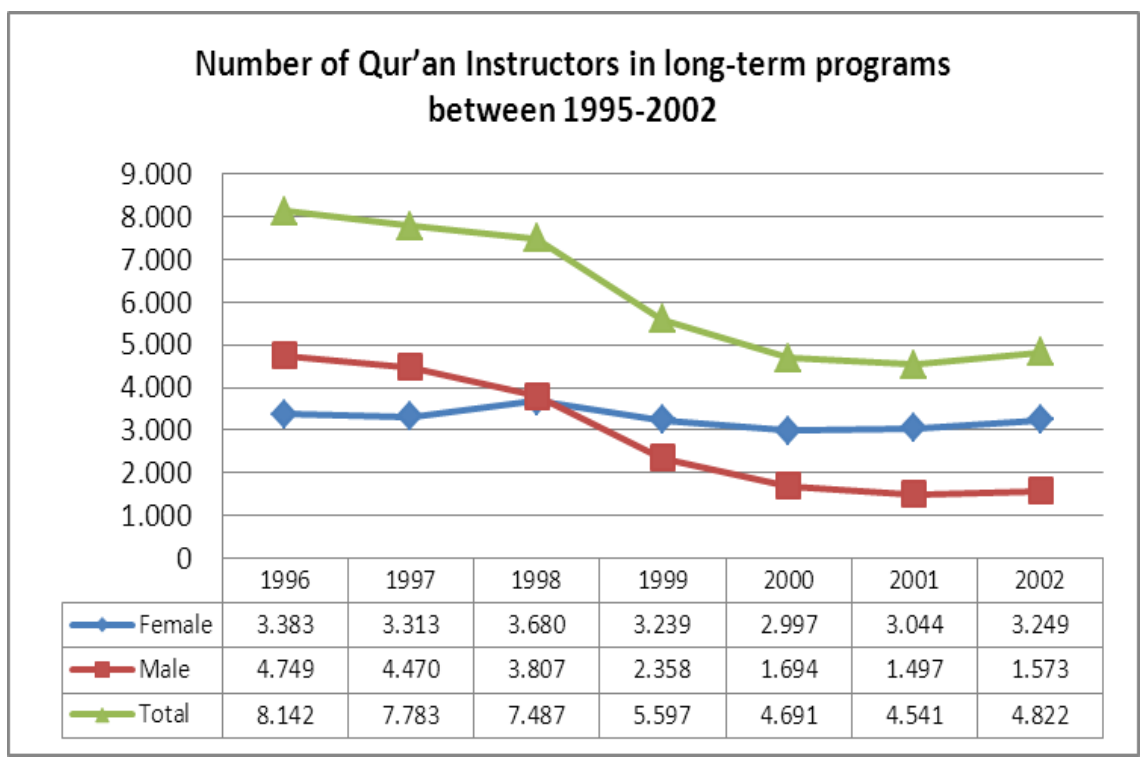

Source: The data were obtained from the Presidency of Religious Affairs of Turkey.

\section{Quantitative Changes to Ḥāfiz Training at Qur'ānic Courses}

Another object of intervention in the wake of February 28 and continuous education law was the "bagfiz training." Upon the actualization of continuous education in 1997, eight year continuous primary-secondary school became compulsory. Consequently, the lectures in Qur'ān and hăfiz training were notably hindered. The number of băfizs was 5.008 in 1998, but it fell to 4.463 in 1999, to 4.292 in 2000, 2.920 in 2001, 1.876 in 2002, and 1.417 in 2003. 


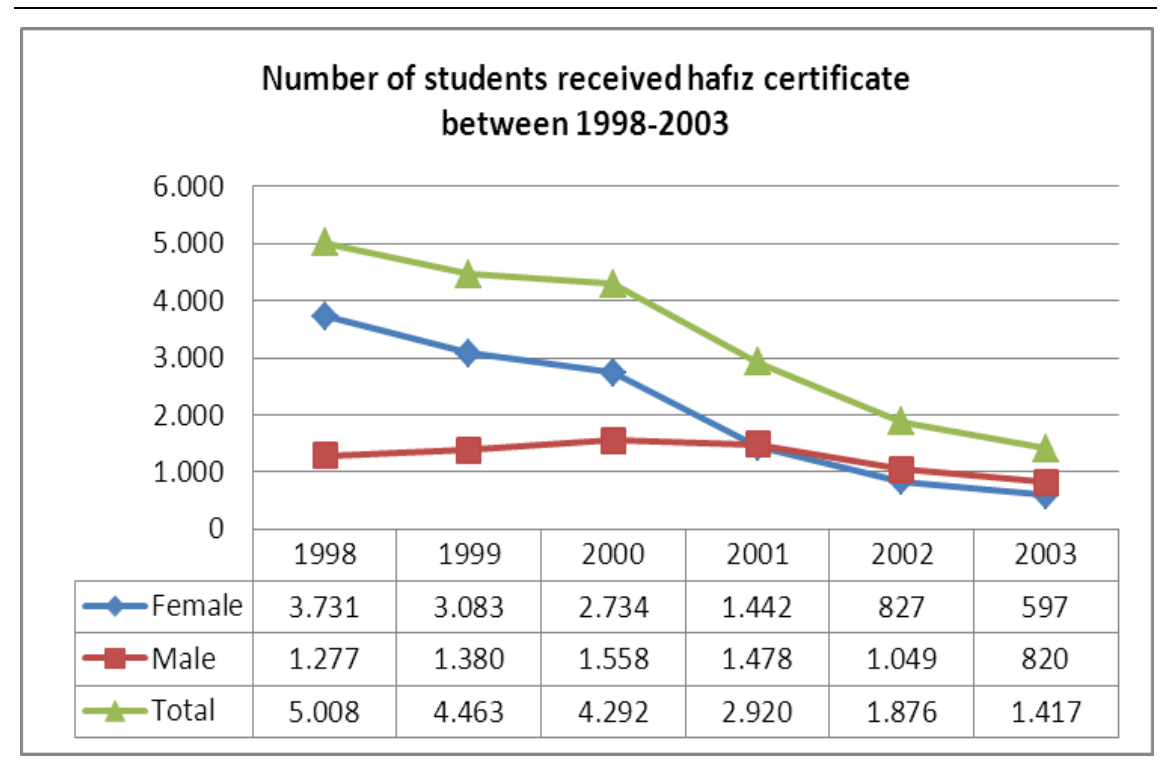

Source: The data were obtained from the Presidency of Religious Affairs of Turkey.

After February 28, Code no. 4415 and Directive no. 23982 stipulated that children attending summer Qur'ānic courses must have graduated from the fifth grade in primary-secondary school. As a result, a sharp drop in the number of students was observed.

In 1999, before the prerequisite, the number of students in the courses was 1.526.466 in 1996, 1.432 .417 in 1997, and 1.294.531 in 1998 , but it dropped to 686.318 in 1999 . As of 2000 , a relative rise in these students has occurred. However, the 1999 enrollment figures were only attained again in 2005 (Bahçekapıl1, 2012: 105). 


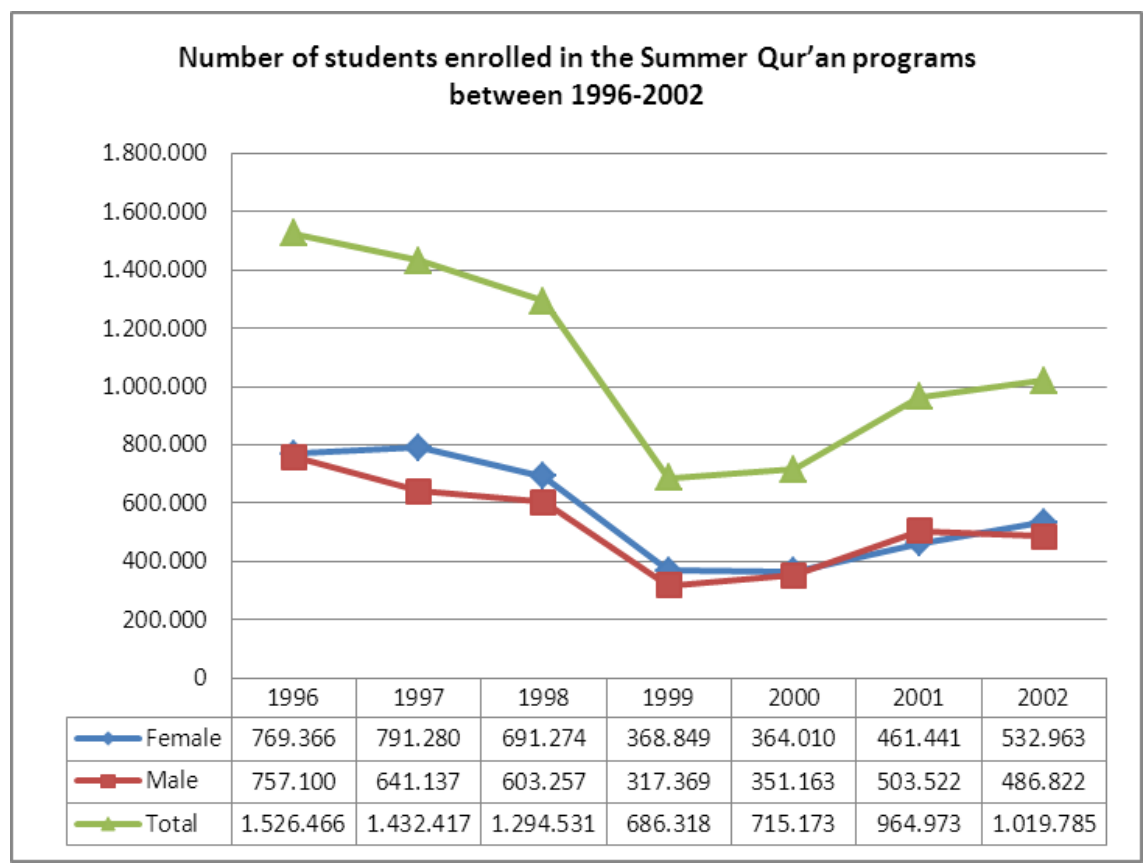

Source: The data were obtained from the Presidency of Religious Affairs of Turkey

\section{Imam-Hatip Schools from 1997 to 2002}

Another educational institution affected by the process of February 28 reforms is Imam Hatip High Schools. Indeed, the primary target of the February 28 intervention was Imam Hatip High Schools. Together with the actualization of eight years of compulsory continuous education, the secondary schools within Imam Hatip High Schools were closed, and no students at secondary school level were allowed as of 1998. In the 1996-1997 academic year, a total of 318.775 students were present in Imam Hatip Secondary Schools. Upon the implementation of the law on compulsory continuous education, these schools graduated the final students and were closed in 1999-2000.

In the 1997-1998 academic year, 59.830 students were enrolled in Imam Hatip High Schools, but the number decreased to 18.391 in 2001-2002. As of 2001-2002, a partial rise was observed. 


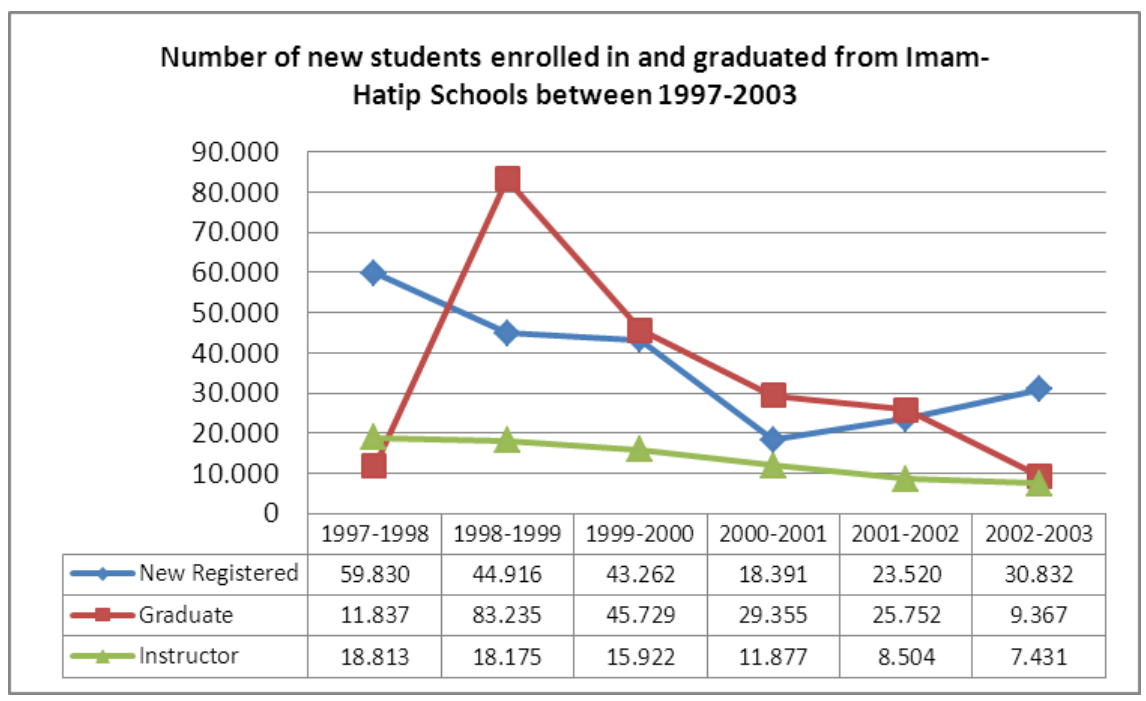

Source: Öcal, 2012: 203.

The conceivers of February 28 reforms were not content with the ability of the law on eight years of compulsory education to block Imam Hatip Schools. Accordingly, the secondary schools within Imam Hatip institutions were closed pursuant to the law. To decrease the popularity of Imam Hatip High Schools, the "coefficient difference per field" came into effect. Prior to the 1999-2000 academic year, all high school graduates were able to enter any higher education program depending on the two-stage "Student Selection and Placement Examination" (ÖSYS) applied by the Student Selection and Placement Center (ÖSYM), regardless of their previous area of specialization. As of 1999, a single examination was applied for student placement in universities, and the Weighted High School GPA (AOBP) came in force. Pursuant to this system, the score of the student at "Student Selection Examination" (ÖSS) was assessed together with the average ÖSS score of his/her high school. On July 30, 1998, with a regulation on article 45 of the Code no. 2547, Council of Higher Education (YÖK) opted for "field coefficient" as of 1999. Thus, the AOBP of Imam Hatip students would be multiplied by 0,5 or 0,2 , depending on whether the chosen program is in their area of specialization, respectively.

Despite the coefficient difference as of 1999, the graduates of Imam Hatip High Schools were able to enter programs other than 
their own, such as law, politics, and various faculties of education. In 2003, YÖK started a new system of coefficient difference to prevent Imam Hatip graduates from enrolling in various programs. According to the rule, the AOBP of graduates of vocational high schools would be multiplied by 0.8 or 0.3 , depending on whether their chosen program is within their area of specialization, respectively (ÖSYM, 2003). Thus, not only the Imam Hatip but all vocational high school graduates were completely excluded from higher education programs other than their own.

The new coefficients for vocational high schools in entering higher education affected both Imam Hatip High Schools students and those of other vocational high schools. Following the application of the regulations, the vocational high schools, which provide training in technical and occupational fields, were no longer able to send students to institutions of higher education.

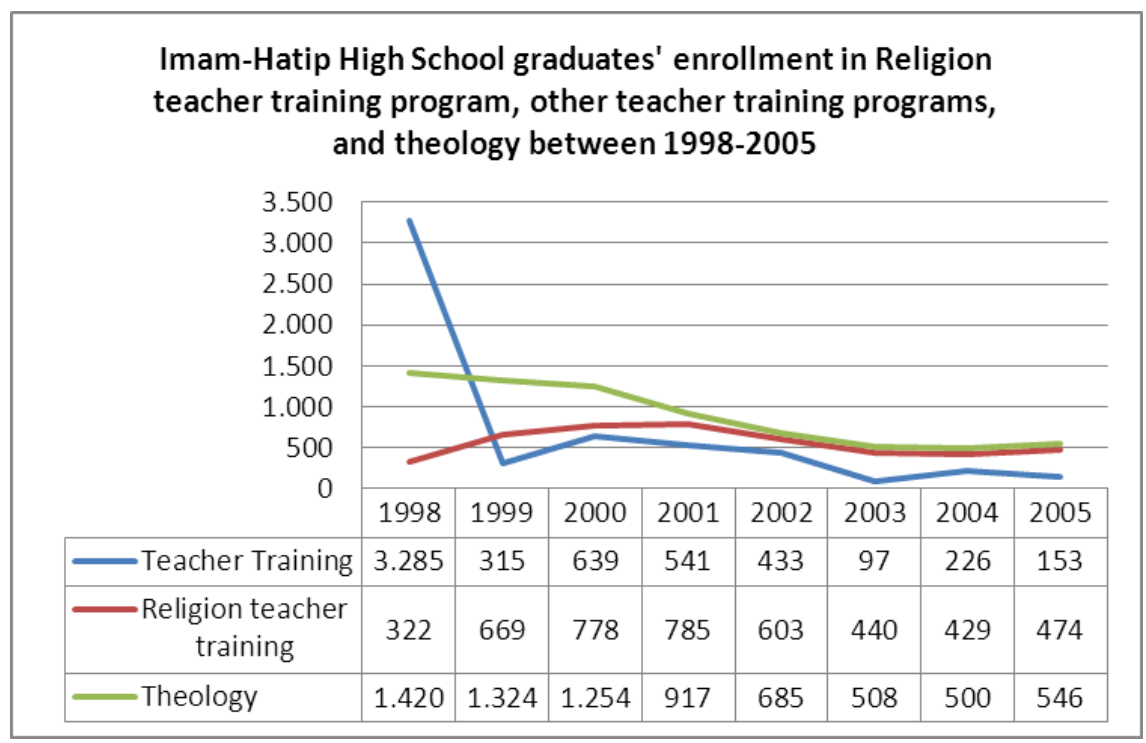

Source: Council of Higher Education (YÖK), 2007: 249 


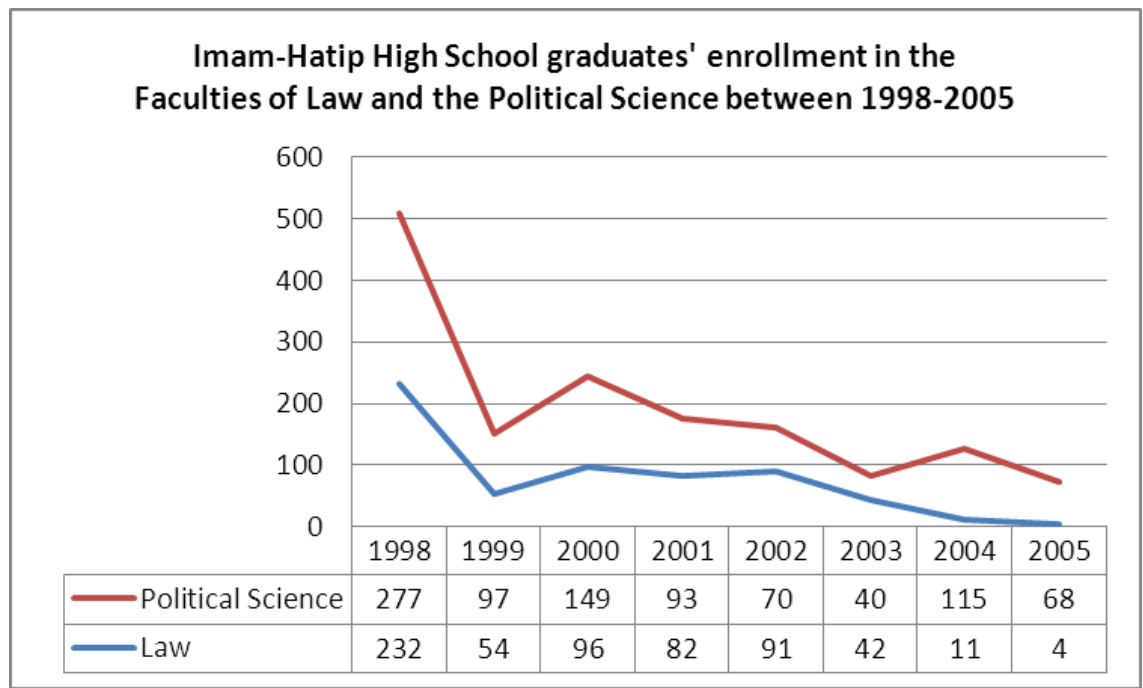

Source: Council of Higher Education (YÖK), 2004: 38; 2007: 249

The Imam Hatip High Schools did trained qualified vocational students and prepared many young people for various education programs. In 1988, the share of Imam Hatip High Schools graduates in undergraduate programs was $3,4 \%$, and the percentage increased to $10,6 \%$ in 1997 , and $12 \%$ in 1998. In 1999, the new coefficient rule caused a notable drop in the number of Imam Hatip High Schools graduates who passed the university entrance exams. The continuous compulsory education and coefficient rule affected the academic success of both Imam Hatip High Schools and all vocational high schools.

Upon such hindrances to Imam Hatip graduates pursuing higher education, the civil initiatives searched for new solutions. The most striking initiative provided possibilities for education abroad for Imam Hatip High Schools graduates so that they can continue their higher education. For example, under the leadership of the Association of Imam Hatip Schools Graduates and Members (ÖNDER), educational services were conducted in Vienna, Austria to ensure higher education for such graduates, and hundreds of students studied subjects such as medicine, architecture, psychology, and engineering at the University of Vienna. 


\section{Religious Higher Education between 1997 and 2002}

Prior to 1982, three types of religious higher education institutions existed in Turkey. Beyond the Faculty of Theology in Ankara, the Higher Institutes of Islam in various cities filled a significant gap in the country together with the Faculty of Islamic Sciences in Erzurum during the years when religious education was abolished. Pursuant to Higher Education Code no. 2547 on November 6, 1982, the number of universities arose to 27 , and all higher education institutions were incorporated within the universities in their respective cities. Consistent with the provisional clause 28 of the code, the religious higher education institutions were transformed into faculties of theology and became a part of the university in the city. In the following process, the faculties of theology became five-year educational institutions with 1 year of preparatory classes and 4 years of undergraduate studies.

The faculties of theology maintained the single program structure from 1982 to 1997, before the reconfiguration of YÖK's decision no. 97.23.1660 on July 11, 1997. From then on, the single-program structure of the faculties was changed, and they comprised two programs: the Undergraduate Program on Theology and the Program of Religious Culture and Moral Knowledge Teaching. Each program accepted its individual students and graduated them. The former theology undergraduate program that enabled pedagogic formation courses graduated its final students in the 2001-2002 academic year. Because no pedagogic formation courses are present in the new undergraduate programs of theology opened in 1998-1999, the students who graduate from these programs have had to earn the non-thesis master degree from Ankara University to become teachers at secondary education institutions. Indeed, the creation of the department on Primary School Teaching of Religious Culture and Moral Knowledge is another attempt to weaken religious higher education because the employment opportunities for theology graduates became fewer and the credits earned for religious/vocational lessons in the department of Primary School Teaching of Religious Culture and Moral Knowledge were decreased. This department was later removed from the Faculty of Theology and incorporated within the Faculty of Education.

In the late 1980s, the 2-year vocational schools of theology were established by the consent of Council of Higher Education to enhance occupational knowledge and skills of religious officials within the Presidency of Religious Affairs. However, they stopped admitting 
students in 1999, and the students eventually disappeared. These schools still admit no students.

An analysis of student quotas in religious higher education indicates a decline after 1999. In 1999, the first teaching program under the faculties of theology admitted 1.280 students, and 640 others could enroll in the Religious Culture and Moral Knowledge Teaching department. The decrease in student quotas continued until 2008. Upon the changes to YÖK personnel by the $60^{\text {th }}$ government of the Republic of Turkey in 2007, the quotas allocated to religious higher education increased.

\section{Religious Education after 2002: A Milestone}

The early general election on November 3, 2002 is one of the milestones of Turkish political history. The election had notable effects both on dominant political parties throughout the process of February 28 and on the position and future of the army that had gradually become dominant in political life since 1960. The election was a turning point for putting democracy into orbit, saving it from becoming a militarist structure. In addition to its political consequences, the election was vital for religious education as well. The political progress as of 2002, namely, the demilitarization and democratization requests, influenced general politics and religious education policies. The legal regulations on religious education encouraged progress consistent with public requests. Consequently, both the public and civil religious education attained a more legitimate structure (Bahçekapıl1, 2012).

\section{Qur'ānic Courses and the Presidency of Religious Affairs}

The legal regulation on July 22, 1999, which imposed age limitation on the children participating in Qurān training, was abolished on September 17, 2011 following a new legal amendment.

In 2004, the Presidency of Religious Affairs (DİB) undertook a reconfiguration of education programs to enhance the quality of education at Qur'ānic courses and to render the activities more efficient and effective.

The content of curricula at long-term Qur'ānic courses was improved. The effects of February 28, together with implementation of eight-year continuous compulsory education, altered the profile and requirements of students. The subjects of faith, prayer, prophetic bi- 
ographies, and morals were added into the curriculum to meet the new requirements.

In addition, the $h \bar{a} f i z$ training program was restructured in 2010 to increase the quality of education and to ensure becoming $h \bar{a} f i z$ in a shorter time. The new $b \bar{a} f i z$ training program consists of three periods: a preparatory class, memorizing, and reinforcement. Each period consists of three basic fields: Qur’ān, Religious Knowledge, and Social Activities. In addition, the program includes 30 course hours per week (DİB, 2010: 8-11).

Today, the "Curricula of Summer Qur'ānic Courses Curricula," prepared by DİB under consent no. 63 on October 11, 2005, are applied in summer Qurānic courses. The education at summer Qur'ānic courses is at least 3 hours per day. The schedule is designed to have 3 classes, each corresponding to a 3 -week education process. The objectives are to provide "the skill of reading the Qur'ān" and "fundamental religious knowledge." The learning domains are classified as Qur’ān, faith, prayer, morals, and biography of the Prophet. One hour is allocated to the Qur'ān and its meaning, and another hour is reserved for lectures on faith, prayer, prophetic biographies and morals (DİB, 2005: 9). A striking point in the curricula of summer Qur'ānic courses is the new "class" system. Pursuant to the new system, students proceed faster than before in learning Qur'ān and basic religious knowledge because they do not have to repeat the formerly gained knowledge and skills. In addition, new textbooks have been prepared to match the new program.

\section{Quantitative Changes to Qur'änic Courses after 2002}

In the wake of elections in 2002, the limitations against religious education were abolished. Consequently, the interest and demand in Qur’ān education notably increased.

In the 2000-2001 academic year, the number of students at longterm Qur'ānic courses the low of 95.437. However, the figures rose to 110.918 in 2001-2002, 118.343 in 2002-2003, 149.871 in 2003-2004, 158.337 in $2004-2005,184.356$ in $2005-2006,230.297$ in 2006-2007, 249.973 in $2007-2008,268.738$ in $2008-2009$, and finally 297.247 in 2009-2010. 


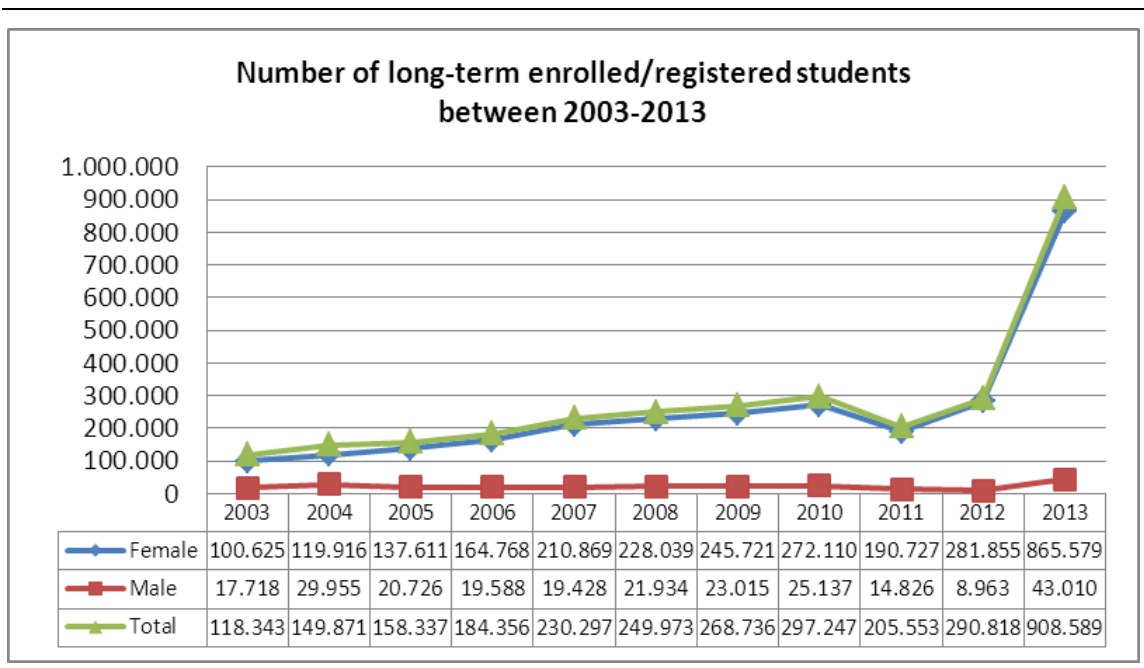

Source: Turkish Statistical Institute (TÜIK), 2010: 302-305. The quantitative data between 2010 and 2013 were obtained from the Presidency of Religious Affairs.

Article 15 under decree law no. 653 on September 17, 2011 abolished the age limitation for Qur'ānic courses. Consequently, the number of students in long-term Qur'ānic courses increased as of the 2011-2012 academic year. The figures rose to 290.818 in 2012 and 908.589 in 2013.

Consistent with the increase in students, the number of Qur'ān teachers and courses also increased significantly. There were 4.822 instructors of long-term Qur'ānic courses in 2001-2002, but the number shifted to 5.484 in 2002-2003, 5.607 in 2003-2004, 6.078 in 2004$2005,3.833^{3}$ in 2005-2006, 10.771 in 2006-2007, and 9.775 in 20072008. Upon the abolition of the age limitation in 2011, the number of instructors increased parallel with student enrollment numbers and became 36.208 (including unpaid, contractual, and permanent instructors).

3 The occasional drop in the number of religious officials within the Presidency of Religious Affairs, such as in 2006, is due to the transition of certain officials to Ministry of National Education as teachers via inter-institutional transfer. 


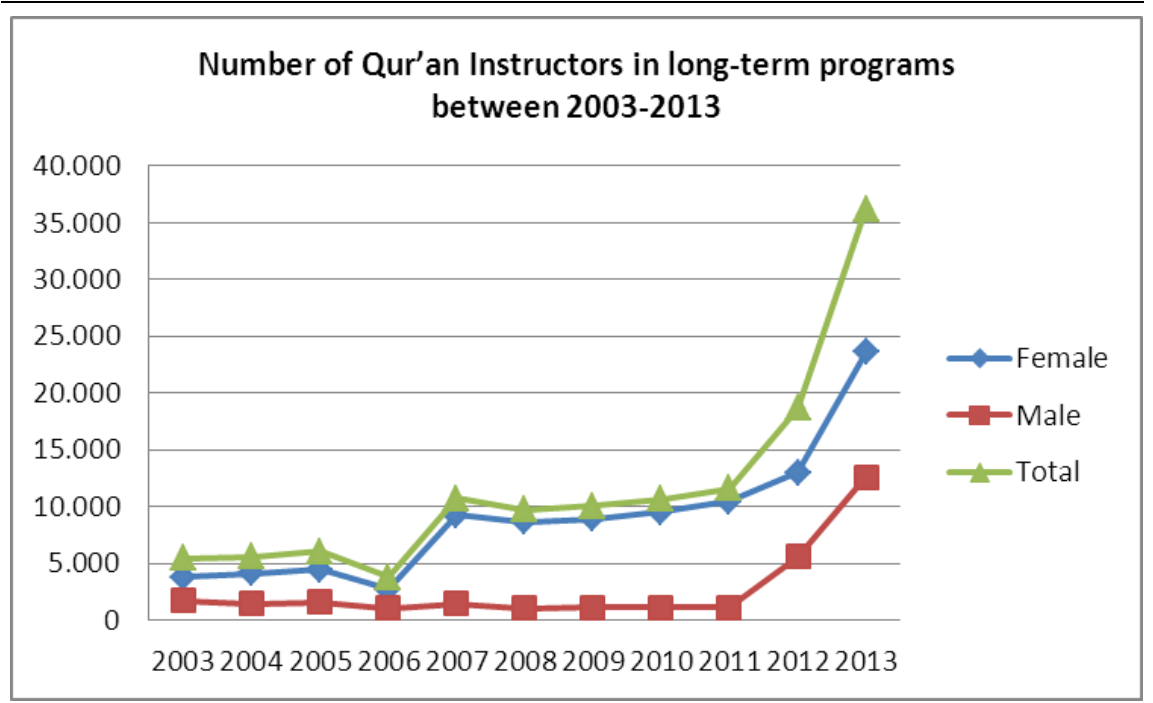

* The figures for the 2012-2013 academic year include unpaid instructors in addition to contractual and permanent teachers.

Source: Turkish Statistical Institute (TÜIK), 2010: 302-305; the quantitative data between 2010 and 2013 were obtained from the Presidency of Religious Affairs.

The number of Qur'ānic courses under the Presidency of Religious Affairs experienced a constant rise throughout Turkey after 2002. There were 3.364 active Qur'ānic courses in 2001-2002, which increased to 3.852 in 2002-2003, 4.322 in 2003-2004, 4.447 in 2004-2005, 4.951 in 2005-2006, 6.033 in 2006-2007, 7.036 in 2007-2008, 7.677 in 2008-2009, 8.696 in 2009-2010, 9.066 in 2010-2011, 13.051 in 20112012, and 13.012 in 2012-2013.

\section{Quantitative Changes in HāfizTraining}

In 1998, 5.008 students were in băfiz training. The figures declined to 2.920 in 2001, 1.876 in 2002 and 1.417 in 2003. As of 2002, due to the liberal atmosphere ensured by the political structure in religious education, certain positive changes were observed in hăfiz training and long-term Qur’ānic courses. 


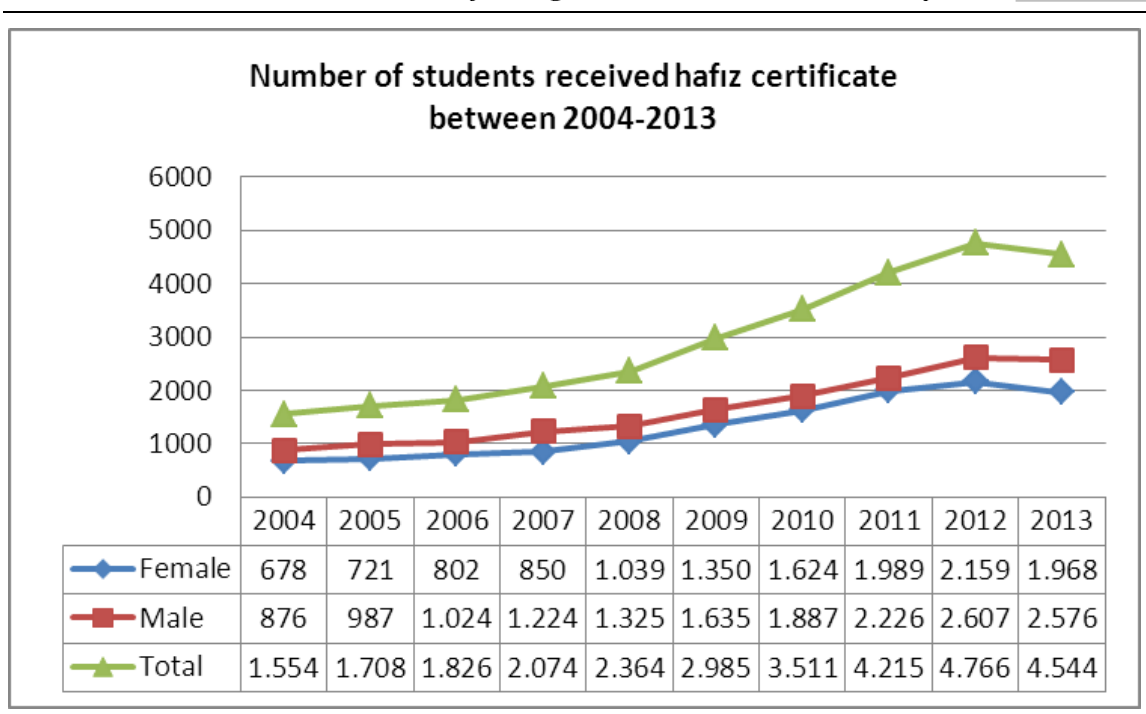

Source: The data between 2010 and 2013 were obtained from the Presidency of Religious Affairs.

Häfiz training lasts 6 months to 2 years. There were 1.554 students who began studies in 2002 and obtained a hăfiz certificate in 2004. The number increased steadily to 1.708 in $2005,1.826$ in 2006, 2.074 in 2007, 2.364 in 2008, 2.985 in 2009, 3.511 in 2010, 4.215 in 2011, and 4.766 in 2012. In 2013, the number of students in häfiz training dropped to 4.544. Between 1998 and 2013, the total number of certified bäfiz has reached 49.523, including 25.594 men and 23.929 women.

\section{Quantitative Changes in Summer Qur'ānic Courses}

Prior to the prerequisite in 1999 of graduation from fifth grade in primary school, the number of students in summer courses was 1.526.466 in 1996. However, 686.318 studied in the courses in 1999. The enrollment numbers decreased briefly in 2000, and the 1996 numbers were not attained again until 2005. The number of students in summer Qur'ānic courses increased remarkably after 2008 with 1.801.150 in 2008, 1.881.637 in 2009 and 1.881.137 in 2010.

As a result of Article 15 under decree law no. 653 on September 17, 2011 abolishing the age limitation for Qur'ānic courses, enrollments in summer Qur'ānic courses increased in all subsequent years except 2011. Student numbers reached 3.203 .562 in 2012 and 3.059 .380 in 2013. Thus, upon the abolition of the age limitation for summer Qurānic courses imposed by February 28 reforms, the stu- 
dent numbers attained the highest level in 2013 and doubled from figures prior to the February 28 intervention.

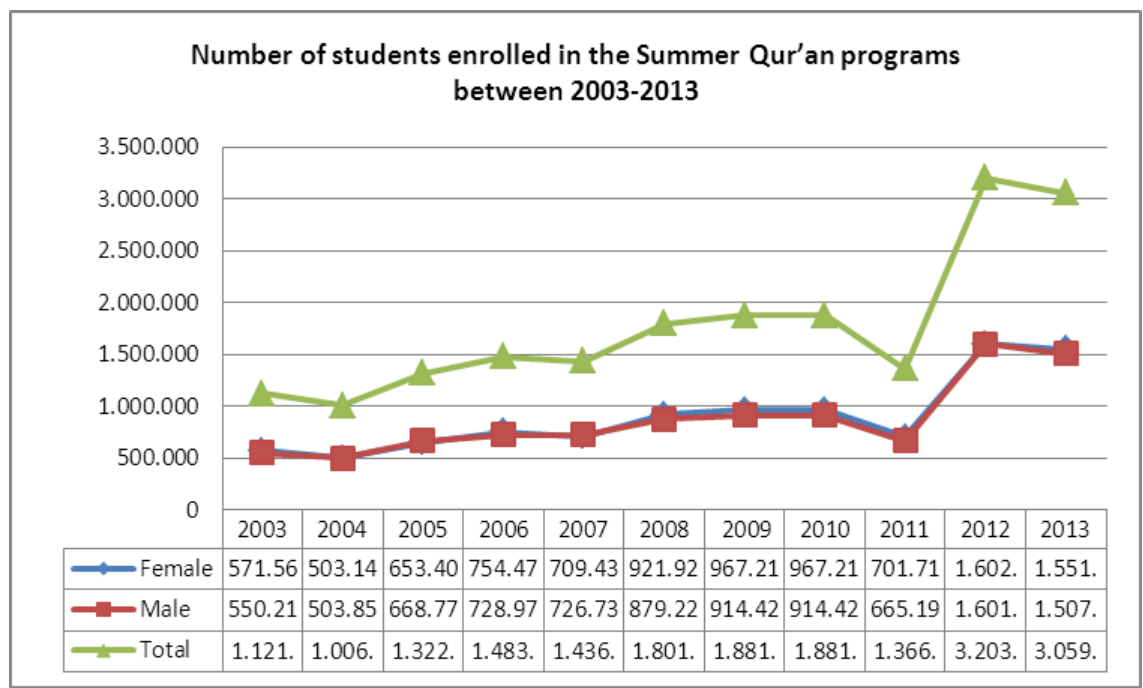

Source: The data were obtained from the Presidency of Religious Affairs of Turkey.

\section{The Reconfiguration of Imam Hatip Schools}

The political power changed hands in 2002, whereupon a remarkable change of policy came into effect regarding Imam Hatip Schools to strengthen their institutional structure. The positive attitude of political power towards Imam Hatip Schools and the expansion in the employment potential of their graduates increased interest in these institutions among students and their parents.

In the 2002-2003 academic year, Imam Hatip High Schools enrolled 64.534 students, and the number increased significantly in 2003-2004 when 84.898 students were enrolled. The enrollments increased further to 96.851 in 2004-2005, 108.064 in 2005-2006, 120.668 in 2006-2007, 129.274 in 2007-2008, 143.637 in 2008-2009, 235.639 in 2009-2010, and 268.245 in the 2011-2012 academic year. 


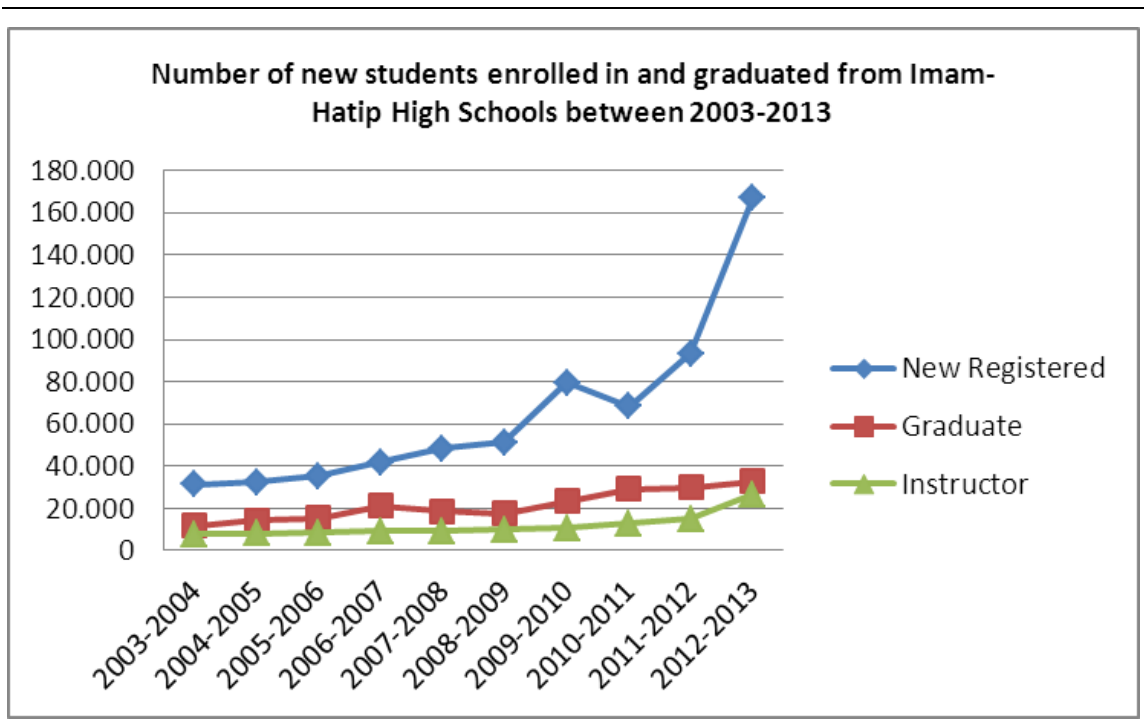

Source. Öcal, 2011: 258; the data between 2011 and 2014 were obtained from the Ministry of National Education.

In 2011 and 2012, Imam Hatip Schools underwent a restructuring process. On December 1, 2011, the coefficient difference against Imam Hatip Schools was abolished. Then, on March 30, 2012, the 12year discontinuous compulsory education of $4+4+4$ came into effect under code no. 6287. The number of Imam Hatip Schools and the number of enrolled students then increased. In 2012-2013 and 20132014, 167.471 and 178.663 students were enrolled in Imam Hatip High Schools, respectively. As a result, the number of students in Imam Hatip High Schools rose to 380.371 in 2012-2013 and 474.135 in 2013-2014.

The number of schools increased parallel to the number of students. There were 537 schools in the 2011-2012 academic year, 711 in 2012-2013, and 846 in 2013-2014.

As the Discontinuous Education Rule of $4+4+4$ came into effect in 2012, primary schools, secondary schools and high schools were no longer interdependent institutions. Thereupon, Imam Hatip Secondary Schools were re-established after a fourteen-year break. As of 2012, it is possible to establish separate Imam Hatip Secondary Schools or to incorporate them within Imam Hatip High Schools, depending on the circumstances. The number of independent Imam Hatip Secondary Schools reached 945 in 2013-2014, enrolling 184.061 students. Four hundred and twenty-three Imam Hatip Secondary 
Schools were established within Imam Hatip High Schools, and they admitted 55.688 students in the 2013-2014 academic year.

Upon the implementation of different coefficients in 1999, the placement rate of Imam Hatip High Schools students in undergraduate programs decreased. The rate was 12\% in 1998, but it fell to approximately 3\% in 2002, 2003, and 2004 (See Ünsür, 2005: 289).

However, the placement rate has increased since 2008 to $13,4 \%$ in $2009,17,6 \%$ in 2010, 13,3\% in 2011, 12\% in 2012, and 14,5\% in 2013.

\section{The Organization of Religious Higher Education}

The first major organization of religious higher education in the post-2002 era came in 2006. Pursuant to decree no. 2006.5.2375 on May 26, 2006 by YÖK, the Elementary School Religious Culture and Moral Knowledge Teaching program was removed from the Faculty of Theology to be incorporated within the Faculty of Education.

Due to the new regulation, a Faculty of Theology exclusively had the undergraduate theology program. This change was notable because the Faculties of Theology, which had trained teachers since 1949 and were defined as "an institution to train teachers" under article 3 of Code no. 3580 in issue 20215 of the Official Gazette on July 04, 1989, were made obsolete in terms of teacher training as of 2006. Another prerequisite required students from undergraduate theology programs to accomplish the exclusive 1,5-year non-thesis master's program within Ankara University to become teachers. In the subsequent years, institutions other than Ankara University were allowed to provide the non-thesis master's program, and its duration was decreased to 1 year. As of 2010, graduates of the theology program may become teachers if they complete a 1-year pedagogical formation process at any Faculty of Education.

The Department of Elementary School Religious Culture and Moral Knowledge Teaching was returned to the Faculty of theology, pursuant to the decree by the Board of YÖK on May 10, 2012. Thus, Faculties of Theology reclaimed their position as teacher-training institutions. According to a new regulation in 2014, the admission of students into the Department of Religious Culture and Knowledge Teaching will stop as of academic year 2014-2015. Therefore, the influences of February 28 on religious higher education are about to vanish. 
Another important issue in religious higher education is that in 2010, the private universities were allowed to establish higher education institutions on religion for the first time. Such enterprises serve as a milestone for the demilitarization of higher education.

In 2010, 23 faculties of theology operated in Turkey, and the number increased to 62 in 2012 and to 96 by June 2014. In 2012, the student quota of faculties of theology reached 13.000, including the Faculties of Islamic Sciences and International Faculties of Islamic and Religious Sciences. The figure reached 15.460 in 2013.

Today, there are 96 Faculties of Theology in Turkey, 51 of which continue student admission and education. Of the faculties, 47 of 51 have daytime education programs with a total student quota of 5515 . There are 41 active evening education programs of theology incorporating 4.805 students. There are 39 departments of Elementary School Religious Culture and Moral Knowledge (DKAB) Teaching in Faculties of Theology, and they enroll 2.820 students. In these faculties, there are 30 evening education programs of DKAB with 2.240 students. As a result, the quota for Faculties of Theology reached 15.460 by 2013 . Ten Faculties of Islamic Sciences, established together with Faculties of Theology, admit students. Four of these are private universities, and the remaining 6 belong to the state. Two Faculties of Islamic Sciences include an "undergraduate program of Islamic sciences." Up to 160 and 80 students are admitted in daytime and evening programs, respectively. Five Faculties of Islamic Sciences comprise "Elementary School Religious Culture and Moral Knowledge Teaching (DKAB)" department with quotas of 320 and 195 for daytime and evening education, respectively. The four private Faculties of Islamic Sciences offer the "undergraduate program of Islamic sciences" with a total quota of 200. The remaining 35 Faculties of Theology do not yet offer education due to lack of academic staff.

\section{Education Reform “4+4+ 4” and Its Effects on Religious Education}

The major event in religious education since 2012 occurred with regard to Education Act $4+4+4$. Pursuant to the new regulation upon the "Code on Amendments on Code of Elementary School and Education and Other Codes" no. 6287 on May 30, 2012, compulsory education in Turkey was changed from eight-year continuous education to twelve years of discontinuous education as $4+4+4$. Previously organized into elementary and secondary education, the education 
system adopted a 3-phase structure with 4 years for each of primary school, secondary school and high school.

By virtue of this act, the secondary schools, which constituted the second stage of elementary education, became independent institutions and included various new learning fields to enable students to discover themselves and their areas of interest. The Ministry of National Education expects the new structure of secondary schools to "enable the growth of students as freer individuals" by means of multiple selective courses (MEB, 2012: 3). The eight-year-long compulsory education requirement was considered the reason behind many problems such as equal opportunities in education, the ability to meet demand and requirements, and compliance with international practices (See Kaymakcan, 2012: 7). Together with the reform, students gained the right to study in institutions consistent with their areas of interest.

\section{The Inclusion of Selective Religious Courses in Primary and Secondary School Programs}

One important reform under the Compulsory Education Act $4+4+4$ is inclusion of new courses on Islam within the curriculum, in addition to Religious Culture and Moral Knowledge that has been studied from $4^{\text {th }}$ to $12^{\text {th }}$ grade since 1982 . Pursuant to decree 69 on June 25, 2012 by the MEB Turkish Education Board, two hours of selective courses titled Qur'ān, the Life of Muhammad, and Basics of Religion are established in the $5^{\text {th }}, 6^{\text {th }}, 7^{\text {th }}$, and $8^{\text {th }}$ grade in secondary school. It is also possible to select these courses for two hours per week in high school grades $9^{\text {th }}, 10^{\text {th }}, 11^{\text {th }}$, and $12^{\text {th }} .{ }^{4}$ The courses are noteworthy because the education schedule is configured in a modular manner. Therefore, students may either select them regularly as of $5^{\text {th }}$ grade or in later grades. In ordinary secondary schools, the courses are available as selectives, whereas they are required the Imam Hatip Secondary School curriculum.

4 In the 2012-2013 academic year, 647.349 secondary school students chose to take the course of Qur'ān, 426.836 students selected course of the Life of Muhammad, and 212.134 students selected the Basics of Religion (the total number of secondary school $5^{\text {th }}$ class students is 1.193.993). As for high schools, the courses on the Qur'ān, the Life of Muhammad, and the Basics of Religion were selected by 385.101, 573.362, and 431.610 students, respectively (the total number of high school $9^{\text {th }}$ grade students is 1.318.260); MEB, 2013. 
Another change as a result of the new education act - courses on the Qur'ān in the curriculum - is unique in the history of religious education. In the Republic of Turkey, these lessons first occurred in the curriculum in 1924 under the title Course on the Qur'an and Religion only to be removed from primary school curriculum in 1930. It is worth noting that a course with the name "Qur'ān" occurs in the curriculum after a eighty-year break.

The course of the Qur'ān aims to ensure that students are aware of the place of the Qur'ān in life, read it in a proper manner, memorize certain chapters and verses and are informed about its content. In this respect, the course is organized into two units from $5^{\text {th }}$ to $8^{\text {th }}$ grade: "the Qur'ān and its message" and "Reading and Memorizing the Qur’ān" (KKÖP, 2012: 6-8)

The main objective of the course "The Life of Muhammad" is to teach the life, personality, and examplariness of the Prophet Muhammad. In this context, the education schedule is based upon 6 fields: "The Life story of Muhammad," "Muhammad in daily life," "Muhammad as an example," "Muḥammad in social life," "Muḥammad and family," and "Muhammad and social communication" (HMHÖP, 2012: 7).

Another selective course on religion is the Basics of Religion. The course aims to ensure that students comprehend the fundamentals of the Muslim faith and are informed about the general features of Islam, its view of life and the universe, basic prayers and their practice, and about basic principles that constitute and sustain the society (İTDBÖP, 2012: 2).

\section{After the New Education Act: Demilitarized Religious Education and Legalization}

The government has played an important part in the development, formation, and progress of religious education since the foundation of the Republic of Turkey. The state has been a decisive, important power regarding the theory and practice of religious education in formal and informal institutions for approximately 90 years. The restrictions or liberalization of religious education occurred in response to government's will. The political will that shapes government has been influential on religious education policies. 
The ebb and flow in religious education after February 28 has followed a course where the political changes are dominant, as observed in diagrams.

The interventions and restrictions against religious education are omnipresent throughout the Republic era, and February 28 was the latest incident. Consequently, the pious public had to search for new methods. Refusing to succumb to governmental oppressions and bans, the religious elements of Turkish society gathered around several civil organizations to establish stronger, more active, and dynamic institutions to transfer their values to posterity. Along with the change of vision for civil religious education, many aspects of education were reconfigured including instructors, curricula, training materials and venues. The Qur'ān and religious sciences were previously taught via traditional methods. However, a student-centered and learning-based approach is popular in modern education centers. The civil religious curriculum is enriched through new areas of learning that will contribute to the socio-cultural and religious development of participants, and training materials are provided.

The most important change to civil religious education is the expansion of the target group. After February 28, public religious education targeted children and youth in formal education and mostly adult women in the informal area. For example, in the 2012-2013 academic year, 95\% of the students at long-term Qur'ānic courses rub by the Presidency of Religious Affairs were women, and men were only 5\%. However, civil religious education targets a vast area without any limitations on age and gender. Informal religious education activities by civil institutions vary in terms of the educational level of participants. Housewives are the most common participants of informal religious services run by the Presidency of Religious Affairs. However, the civil religious education activities attract women from various educational levels and lines of business. That the women are more active participants in both types of activities is indeed an unexpected consequence, even for the actors of February 28. The conservative and relatively undereducated women made good use of the process and succeeded in enhancing their educational level in general knowledge and in religion in particular.

Another important development in civil religious education occurred in this period: the gradual professionalization of institutional structures. Religious education activities were previously limited by the inner structure of orders and communities who undertook civil 
religious education. Subsequently, the activities enjoyed a notable outward expansion. The religious education activities became institutionalized. Teachers and instructors, who once worked as public servants but had to leave for various reasons, focused on civil religious education and transferred their knowledge to the civil domain. Consequently, civil activities gradually became more professional.

The supportive government policies since 2002, particularly as of 2011, and the positive changes in formal and informal religious education, lead to discussions about the future. According to data from our survey, most people who enter religious service argue that governmental supervision and control of religious education should continue. Conversely, many people believe that the state's role in religious education should end. In other words, they are uneasy with governmental intervention in religious education. In general, both groups want the government to be supportive in structural terms and supervise quality so that the religious education appeals to broader masses with higher quality. Moreover, both groups seek a system where the civil institutions have executive authority (Bahçekapilı, 2012).

Almost 2,5 million students choose selective courses about religion during formal education; 900.000 people participate in longterm Qur'ānic courses within the scope of informal religious education, and another 3 million attend summer Qur’ānic courses. These figures render the future of civil religious education debatable. Upon the abolition of the age limit for informal religious education, the number of students increased dramatically in 2012. By 2013, the boom proceeded and surpassed the previous figures many times more. According to one study (Bahçekapıl1, 2012: 235), the citizens choose public religious education primarily due to their confidence in the state, though factors such as quality, efficiency and sustainability also play a part. Nevertheless, the quantitative rise in public religious services may lead to a qualitative degradation in upcoming years due to the lack of instructors and training spaces. On such an occasion, religious education may regress in quality and efficiency and fail to meet the expectations, perhaps causing civil religious education to become popular again. The Presidency of Religious Affairs provides approximately 4 million citizens with religious services per year, but almost $80 \%$ of these activities take place in mosques that are not suitable for education, and the institution cannot employ as many religious officials as needed. Similarly, the formal religious education by 
the Ministry of National Education faces a serious shortage of teachers. The shortage is 18.000 teachers for the 2013-2014 academic year, and the figure is expected to reach 50.000 in the upcoming years. The deficiencies of public religious education may gradually pave the way for increased interest in civil religious education. In this regard, the government should realize the necessary legal regulations for ensuring alternatives to civil religious education. The government should stop supporting state-based religious education and develop a new approach and system based on the collaboration between government and civil initiatives.

\section{Conclusion}

The ebb and flow in approaches and practices regarding religious education in Turkey has been closely related to political changes. Since the early years of the Republic, the policies against religion and religious education were based on the modernity perceptions of Kemalist ideology. This perception, and the secular approach and practices, were seriously influential on the matter. This process in the early Republic era was in stark contrast to the religious values, comprehension, worldview, and lifestyle of most of the Turkish public. Consequently, such policies could not achieve consistency and followed a fluctuating course. Similar to those before and after 1950, the developments after February 28, 1997 are clear indicators of this fact.

The process of February 28 reform implementation can be considered an important moment for development and reform in religious education and for the establishment of new tendencies. The process of the February 28 reforms was apparently a political and military counterstrike. The underlying project was a type of social engineering. In this respect, February 28 and the following period is almost a symbol of long-lasting governmental intervention on religion and the attitude against such intervention.

After the February 28 intervention, Qur'ānic courses, Imam Hatip High Schools, and Faculties of Theology were subject to erosion in legal and structural terms. Apart from the interventions on religious education institutions, girls were deprived of their right to education due to the headscarf ban, and the future of many Imam Hatip High Schools students was blocked because of coefficient differences. All these realities had destructive effects on the religious portion of society. 
As of 2002, the political developments, efforts to demilitarize and democratize influenced religious education policies and the general politics of Turkey. In this era, legal regulations on religious education contributed to a more independent progress in the field. Such moves ensured a more legitimate structure for religious education through both the government and civil initiatives. However, because religious education was neglected for a long time and the developments suffered occasional obstacles, the scientific view on the field was negatively affected and eventually led to an eclectic structure.

In this context, the society has various expectations from both the government and civil initiatives. Above all, the religious education should be designed to cover all section of society. To that end, a need exists for a philosophical view of what type of individuals we want to teach and for developing this type of projects.

One of the notable results of this study is that the civil aspect of religious education should be reinforced to ease the effects of politics and its ebbs and flows. Therefore, various centers should be established to support the religious education field, and the affairs should be managed by and around such centers. Because centers under total governmental control cannot avoid political interventions, the civil society must be eager and supportive of a more independent mode of religious education in Turkey.

\section{REFERENCES}

Bahçekapilı, Mehmet, Türkiye'de Din Eğitiminin Dönüşümü (1997-2012) (Istanbul: İlke Yayınlan, 2012).

Başgil, Ali Fuat, Din ve Laiklik (Istanbul: Yağmur Yayınlan, 1998).

Can, Osman, Darbe Yargısının Sonu (Istanbul: Timaş Yayınları, 2010).

Cizre, Ümit, Muktedirlerin Siyaseti: Merkez Să̆-Ordu-İslâmcıllk (Istanbul: İletişim Yayınları, 2005).

Commins, David Dean, Osmanl Suriyesi'nde Islahat Hareketleri (translated into Turkish by Selahaddin Ayaz; Istanbul: Yöneliş Yayınlanı, 1993).

Çakır, Ruşen, Ne Şeriat Ne Demokrasi (Istanbul: Metis Yayınları, 1994).

Demirel, Ahmet, ilk Meclis'in Vekilleri: Milli Mücadele Döneminde Seçimler (Istanbul: İletişim Yayınlanı, 2010).

DİB (Diyanet İşleri Başkanlığ/Presidency of Religious Affairs), Kur'an Kursları Öğretim Programı (Ankara, 2004).

DİB (Diyanet İşleri Başkanlığ1/Presidency of Religious Affairs), Yaz Kur'an Kursları Öğretim Programları (Ankara, 2005). 
DİB (Diyanet İşleri Başkanlığı/Presidency of Religious Affairs), Hafizlık Ĕ̆itim Programı (Ankara, 2010).

DİB (Diyanet İşleri Başkanlığı/Presidency of Religious Affairs), Kur'an Kurslar Öğretim Programlar (pilot uygulama) (Ankara, 2011).

HMHÖP, Hz. Muhammed'in Hayatı Dersi Öğretim Programı (Ankara: MEB, 2012).

İnal, Kemal, "Türkiye'de Geçmişten Günümüze Din Politikalanı ve Eğitime Etkileri," Değerler Eğitimi Merkezi Dergisi 1/2, (2007) 12-17.

İTDBÖP, Imam Hatip Ortaokulu Temel Dini Bilgiler Dersi Öğretim Programı (Ankara: MEB, 2012).

Kaymacan, Recep, 4+4+4 Eğitim Sistemi, Yeni Anayasa'da Dini Kurumlar, Din Eğitimi ve Öğretimi, İsteğe Bağh Din Eğitimi (Istanbul: Ensar Vakfı, 2012).

Kesgin, Safiye, "Cumhuriyet Dönemi Örgün Eğitim Kurumlarında Ahlak Eğitimi," Ankara Üniversitesi İlabiyat Fakültesi Dergisi 52/1, (2011) 209-238.

KKÖP, Ortaokul ve IHLL Kur'an-ı Kerim Dersi Öğretim Programı (Ankara: MEB, 2012).

Koçak, Cemil, Tek-Parti Döneminde Mubalif Sesler (2 ${ }^{\text {nd }}$ edn.; Istanbul: İletişim Yayıncilik, 2011).

MEB, 222 Sayıl Illköğretim ve Eğitim Kanunu ile Bazı Kanunlarda Yapılan Değişiklik Sonucu Getirilen Yenilikler (Ankara: MEB, 2012).

MEB, 1997-2013 Yillam Arası Yeni Kaynt ve Toplam Öğrenci Sayıları (Ankara: MEB, 2013).

MGKK, (Milli Güvenlik Kurulu Kararı), date: February 28, 1997, no: 406.

Okumuş, Ejder, "Osmanlı Devleti'nde Modernleșme Süreci," in Ejder Okumus (ed.) Osmanh Devleti'nde Eğitim Hukukve Modernleşme (Istanbul: Ark Kitaplan, 2006).

Öcal, Mustafa, Osmanlidan Günümüze Türkiye'de Din Eğitimi: Mukaddime Kitap (Bursa: Düşünce Kitabevi Yayınları, 2011).

- "İmam Hatip Liselerinde Din Eğitimi" in Nurullah Altaş and Mustafa Köylü (eds.), Din Eğitimi (Ankara: Gündüz Eğitim ve Yayıncllk, 2012), 177-211.

ÖSYM (T.C. Ölçme, Seçme ve Yerleştirme Merkezi) "2003-ÖSS Öğrenci Seçme Sınavı puan hesaplamaları ile ilgili değişiklikler basın duyurusu”, 2003.

Özdalga, Elisabeth, İslâmcilı̆ın Türkiye Seyri: Sosyolojik Bir Perspektif(Istanbul: İletişim Yayınları, 2007).

Subaşı, Necdet, Ara Dönem Din Politikalar (Istanbul: Küre Yayınları, 2005).

Tuna, Korkut, Yeniden Sosyoloji (Istanbul: İz Yayıncilık, 2013).

Ünsür, Ahmet, Imam Hatip Liseleri - Kuruluşundan Günümüze (Istanbul: Ensar Neşriyat, 2005).

YÖK (Yükseköğretim Kurulu/Council of Higher Education), Türk 
Yükseköğretiminin Bugünkü Durumu (Ankara Üniversitesi Basımevi: Ankara, Kasım 2004).

YÖK (Yükseköğretim Kurulu/Council of Higher Education), Türkiye'nin Yükseköğretim Stratejisi (Meteksan A.Ş: Ankara, Şubat 2007). 